\title{
Sesquiterpene Lactones from Minasia alpestris
}

\author{
Antônio Eduardo M. Crotti ${ }^{a}$, Wilson R. Cunha ${ }^{b}$, Norberto P. Lopes ${ }^{c}$ and João Luis C. Lopes ${ }^{*, c}$ \\ ${ }^{a}$ Departamento de Química, Faculdade de Filosofia, Ciências e Letras, Universidade de São Paulo, \\ Av. Bandeirantes 3900, 14040-901 Ribeirão Preto - SP, Brazil \\ ${ }^{b}$ Núcleo de Pesquisas em Ciências Exatas e Tecnológicas, Universidade de Franca, \\ Av. Dr. Armando Salles de Oliveira 201, 14404-600 Franca - SP, Brazil \\ ${ }^{c}$ Departamento de Física e Química, Faculdade de Ciências Farmacêuticas de Ribeirão Preto, \\ Universidade de São Paulo, Via do Café s/n, 14040-903 Ribeirão Preto - SP, Brazil
}

\begin{abstract}
A investigação química das folhas de Minasia alpestris forneceu dois novos furanoeliangolidos, bem como sete lactonas sequiterpênicas conhecidas. As estruturas foram elucidadas através de métodos espectroscópicos.

The chemical investigation of the Minasia alpestris leaves afforded two new furanoheliangolides in addition to seven known sesquiterpene lactones. The structures were elucidated by spectroscopic methods.
\end{abstract}

Keywords: Minasia alpestris, Asteraceae, sesquiterpene lactones, furanoheliangolide

\section{Introduction}

The tribe Vernonieae is composed of 98 genera and approximately 1300 species and is divided into 10 subtribes. ${ }^{1}$ Most of these species are concentrated in the Americas and several of them are endemic to Brazil. Minasia is a small herbaceous genus, endemic to Minas Gerais State, Brazil. ${ }^{2}$ This genus is placed in the subtribe Lychnophorinae, where the occurrence of sesquiterpene lactones of the furanoheliangolide type is very common. The anti-inflammatory activity of these compounds was recently demonstrated as being due to their ability to inhibit the $\mathrm{nF}-\mathrm{kB}$ transcription factor during the inflammatory process. ${ }^{3}$ Some species of the subtribe from which furanoheliangolides has been isolated, such as in case of Lychnophora ("false arnica"), are widely used in folk medicine. The recent inclusion of Lychnophora among the arboreous species under risk of extinction has stimulated studies on the herbaceous species of the subtribe due to their ease of propagation. Although there is no reported use of the Minasia species, the chemical investigation of Minasia alpestris (Gardner) H. Robinson,

* e-mail: joaoluis@usp.br the first of the five known species of the genus to be investigated,,$^{2,45}$ has significance in that the investigation demonstrated their use as a potential source of furanoheliangolides rather than other arboreous species of Lychnophorinae. This species was originally placed in the Chresta and Vernonia genera by Gardner and Baker. ${ }^{1,2}$

\section{Experimental}

General

${ }^{1} \mathrm{H}(400 \mathrm{MHz})$ and ${ }^{13} \mathrm{C}$ NMR (100 MHz) spectra were recorded on a Brüker DPX-400 in $\mathrm{CDCl}_{3}$ with TMS as internal standard. FT-IR was obtained on a Nicolet Protege $460\left(\mathrm{CHCl}_{3}\right)$. Optical rotations were measured on a Polamaco Jasco DIP-370. High-resolution ESI-MS were recorded on a Micromass Q-Tof mass spectrometer. Preparative HPLC (P-HPLC) was performed on ODS column ( $5 \mu \mathrm{m}, 25 \times 2 \mathrm{~cm}$ i.d.), Shimadzu; Centrifugal thin layer chromatography (CTLC) ${ }^{6}$ was carried out on Chromatotron 8942 over silica gel Merck 7749. CC was performed over silica gel 60. Analytical and preparative thin layer chromatography (TLC) were performed over silica gel $60 \mathrm{GF}_{254}$ and silica gel $\mathrm{PF}_{254+366}$, respectively. Spot detection was made by either using a UV light at $254 \mathrm{~nm}$ and/or spraying with $\mathrm{H}_{2} \mathrm{SO}_{4}$. 


\section{Plant material}

Minasia alpestris was collected near Conselheiro Mata, State of Minas Gerais, Brazil, in July 1998. A voucher specimen (VW 454) is deposited at the Herbarium of the Instituto de Biologia, UNICAMP, Campinas - SP.

\section{Extraction and isolation}

Dried leaves of the plant $(2.1 \mathrm{~kg})$ were dehydrated, powdered, exhaustively and sequentially extracted with $\mathrm{CH}_{2} \mathrm{Cl}_{2}$ and $\mathrm{EtOH}$. A sample $(20 \mathrm{~g})$ of the $\mathrm{CH}_{2} \mathrm{Cl}_{2}$ extract was dissolved with a minimum volume of $\mathrm{MeOH}: \mathrm{H}_{2} \mathrm{O}(9: 1$ $\mathrm{v} / \mathrm{v}$ ) and successively partitioned with hexane and $\mathrm{CH}_{2} \mathrm{Cl}_{2}$ ( 3 x $500 \mathrm{~mL}$ ). The dichloromethane phase was concentrated under reduced pressure. The resulting dichloromethane fraction $(2.74 \mathrm{~g})$ was fractionated by $\mathrm{CC}(150 \mathrm{~g}, 7 \mathrm{~cm})$ using a $n$-hexane:EtOAc gradient to yield 5 major fractions (frs. 5-10).

Fr. 5 ( $n$-hexane:EtOAc 4:1, $374 \mathrm{mg}$ ) was chromatographed over silica gel by CTLC ( $n$-hexane:EtOAc $1: 1$ ) to give 5 subfractions. 15-deoxygoyazensolide (40 mg), 2', 3'dihydro-15-deoxygoyazensolide $(5.0 \mathrm{mg})$ and $8 \alpha$ tigloyloxy-15-deoxygoyazensolide $(3.0 \mathrm{mg})$ were isolated from subfr. 5.1 (82 mg) by P-HPLC (MeOH: $\mathrm{H}_{2} \mathrm{O}$ 1:1). 2', 3'Epoxy-15-deoxygoyazensolide $(3.0 \mathrm{mg})$ was purified from fr. 6 ( $n$-hexane:EtOAc 4:1, $34 \mathrm{mg}$ ) by Preparative TLC (PTLC) $\left[\mathrm{CHCl}_{3}:\left(\mathrm{CH}_{3}\right)_{2} \mathrm{CO} 9: 1\right]$. P-TLC $\left[\mathrm{CHCl}_{3}:\left(\mathrm{CH}_{3}\right)_{2} \mathrm{CO} 9: 1\right]$ of fr.7 ( $n$-hex:EtOAc 4:1, $81 \mathrm{mg}$ ) yielded eremantholide $\mathrm{C}$ $(10 \mathrm{mg})$ and subfr. $7.7(13 \mathrm{mg})$ which was purified by $\mathrm{P}-$ HPLC (MeOH: $\left.\mathrm{H}_{2} \mathrm{O} 1: 1\right)$ to give 1 (3.0 mg). Fr. 8 (nhex:EtOAc 3:2, $61 \mathrm{mg}$ ) was submitted to P-TLC $\left[\mathrm{CHCl}_{3}:\left(\mathrm{CH}_{3}\right)_{2} \mathrm{CO} \quad 17: 3\right]$ yielding $8 \beta$-hydroxygoyazensanolide $(25 \mathrm{mg})$. Fr. 9 ( $n$-hexane:EtOAc 3:2, 70 $\mathrm{mg}$ ) was successively submitted to P-TLC $\left[\mathrm{CHCl}_{3}:\left(\mathrm{CH}_{3}\right)_{2} \mathrm{CO}\right.$ 17:3] whose main fraction $(15 \mathrm{mg})$ was re-purified by P-TLC to give $2(3.0 \mathrm{mg})$. Fr. 10 ( $n$ hexane:EtOAc 1:1, $79 \mathrm{mg}$ ) was purified by P-HPLC (MeOH: $\mathrm{H}_{2} \mathrm{O} 2: 3$ ) to give goyazensolide (12 mg).

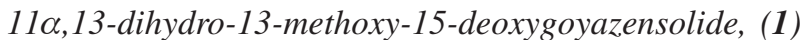

(3 mg, 0.015\%); colourless gum; $[\alpha]_{589}{ }^{25}=+23.53(c$ $\left.0.05, \mathrm{CHCl}_{3}\right)$; IR $\left(\mathrm{CHCl}_{3}\right.$ film $) v_{\max } / \mathrm{cm}^{-1}: 2979,2931,1774$, 1709, 1656, 1636, 1582, 1448, 1376, 1292, 1138, 1024, 916; ${ }^{1} \mathrm{H} \mathrm{NMR}\left(\mathrm{CDCl}_{3}, 400 \mathrm{MHz}\right): \delta 5.73$ (s, 1H, H-2), 5.97 (dq, $J 1.0$ and $2.3 \mathrm{~Hz}, 1 \mathrm{H}, \mathrm{H}-5$ ), 5.09 (ddq, $J$ 1.5, 2.3 and $8.1 \mathrm{~Hz}, 1 \mathrm{H}, \mathrm{H}-6), 3.45$ (ddd, J 2.0, 8.1 and $10 \mathrm{~Hz}, 1 \mathrm{H}, \mathrm{H}-7$ ), 4.89 (ddd, $J 2.0$ and $10.8 \mathrm{~Hz}, 1 \mathrm{H}, \mathrm{H}-8$ ), 2.39 (dd, $J 10.8$ and $13.8 \mathrm{~Hz}, 1 \mathrm{H}$. H-9 $\alpha$ ), 2.14 (dd, $J 2.0$ and 13.8, $1 \mathrm{H}, \mathrm{H}-9 \beta$ ), 2.55 (dt, J 4.0 and $10.0 \mathrm{~Hz}, 1 \mathrm{H}, \mathrm{H}-11$ ), 3.73 (dd, $J 4.0$ and
$9.6 \mathrm{~Hz}, 1 \mathrm{H}, \mathrm{H}-13 \mathrm{a}), 3.56$ (dd, J 4.0 and $9.6 \mathrm{~Hz}, 1 \mathrm{H}, \mathrm{H}-13 \mathrm{~b}$ ), 1.50 (s, $3 \mathrm{H}, \mathrm{H}-14$ ), 2.10 (dd, 1.0 and $1.5 \mathrm{~Hz}, 3 \mathrm{H}, \mathrm{H}-15$ ), 6.08 (dq, $J 1.8$ and $1.5 \mathrm{~Hz}, 1 \mathrm{H}, \mathrm{H}-3$ ' $a$ ), 5.62 (dq, $J 1.0$ and $1.8 \mathrm{~Hz}, 1 \mathrm{H}, \mathrm{H}-3^{\prime} b$ ), 1.90 (dd, 1.0 and $1.5 \mathrm{~Hz}, 3 \mathrm{H}, \mathrm{H}-4^{\prime}$ ), 3.39 (s, $3 \mathrm{H}, \mathrm{OCH}_{3}$ ), H-13a and $\mathrm{H}-13 \mathrm{~b}$ can be exchanged; ${ }^{13} \mathrm{C}$ NMR, DEPT 135 , HMQC and HMBC (100 MHz, $\mathrm{CDCl}_{3}$ ): $\delta 204.5$ (s, C-1), 104.7 (d, C-2), 186.8 (s, C-3), 128.8 (s, C-4), 133.8 (d, C-5), 80.9 (d, C-6), 48.8 (d, C-7), 69.8 (d, C-8), 43.3 (t, C-9), 89.0 (s, C-10), 44.3 (d, C-11), 174.9 (s, C-12), 70.1 (t, C-13), 20.4 (q, C-14), 21.2 (q, C-15), 166.3 (s, C-1'), 135.2 (s C-2'), 127.0 (t, C-3'), 18.1 (q, C-4'), $59.2\left(\mathrm{q}, \mathrm{OCH}_{3}\right)$; ESI-MS $[\mathrm{M}+\mathrm{Na}]^{+}$Found: $\mathrm{m} / \mathrm{z}$ 399.1414. Calc. for $\mathrm{C}_{20} \mathrm{H}_{21} \mathrm{O}_{7} \mathrm{Na}$ : 399.1420.

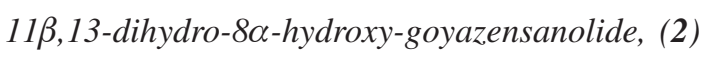

(3 mg, 0.015\%), yellow gum, $[\alpha]_{589}{ }^{25}=+9.92(c 0.13$, $\mathrm{CHCl}_{3}$, ); IR $\left(\mathrm{CHCl}_{3}\right.$ film) $v_{\max } / \mathrm{cm}^{-1}: 3456,2934,1769$, $1703,1655,1573,1447,1379,1291,1177,1141,983 ;{ }^{1} \mathrm{H}$ NMR (400 MHz, $\mathrm{CDCl}_{3}$ ): $\delta 5.67$ (s, H-2), 5.98 (dq, $J 1.7$ and $2.2 \mathrm{~Hz}, 1 \mathrm{H}, \mathrm{H}-5), 4.70$ (ddq, J 2.0, 2.2 and $8.9 \mathrm{~Hz}, 1 \mathrm{H}$, H-6), 2.82 (ddd, J 2.0, 8.9 and $9.4 \mathrm{~Hz}, 1 \mathrm{H}, \mathrm{H}-7$ ), 3.76 (dt, $J$ 2.0 and $10.8 \mathrm{~Hz}, 1 \mathrm{H}, \mathrm{H}-8), 2.24$ (dd, $J 10.8$ and $13.5 \mathrm{~Hz}, 1$ H, H-9 $\alpha$ ), 2.08 (dd, J 2.0 and 13.5 Hz, $1 \mathrm{H}, \mathrm{H}-9 \beta$ ), 3.14 (dq, $J 7.0$ and $9.4 \mathrm{~Hz}, 1 \mathrm{H}, \mathrm{H}-11), 1.31$ (d, J 7.0 Hz, $3 \mathrm{H}, \mathrm{H}-13)$, 1.48 (s, 3 H, H-14), 2.09 (dd, $J 1.7$ and $2.0 \mathrm{~Hz}, 3 \mathrm{H}, \mathrm{H}-15$ ); ${ }^{13} \mathrm{C}$ NMR, DEPT $135^{\circ}$, HMQC and HMBC (100 MHz, $\left.\mathrm{CDCl}_{3}\right): \delta 205.0$ (s, C-1), 104.7 (d, C-2), 187.4 (s, C-3), 128.6 (s, C-4), 133.7 (d, C-5), 80.9 (d, C-6), 55.8 (d, C-7), 65.6 (d, C-8), 48.4 (t, C-9), 89.9 (s, C-10), 36.9 (d, C-11), 178.2 (s, C-12), 15.9 (q, C-13), 20.5 (q, C-14), 21.4 (q, C15); ESI-MS [M+Na] ${ }^{+}$Found: $m / z$ 301.1046. Calc. for $\mathrm{C}_{15} \mathrm{H}_{18} \mathrm{O}_{5} \mathrm{Na}: 301.1052$ ).

\section{Results and Discussion}

The dichloromethane extract of the leaves afforded the new furanoheliangolides $\mathbf{1}$ and $\mathbf{2}$ (Figure 1) in addition to the known sesquiterpene lactones 15-deoxygoyazensolide, ${ }^{7}$ goyazensolide, ${ }^{8}$ 2', 3' -dihydro-15deoxygoyazensolide, ${ }^{9} 8 \alpha$-tigloyloxy-goyazensanolide, ${ }^{10}$ 2',3'-epoxy-15-deoxygoyazensolide, ${ }^{11} 8 \beta$-hydroxygoyazensanolide $^{9}$ and eremantholide C. ${ }^{12}$
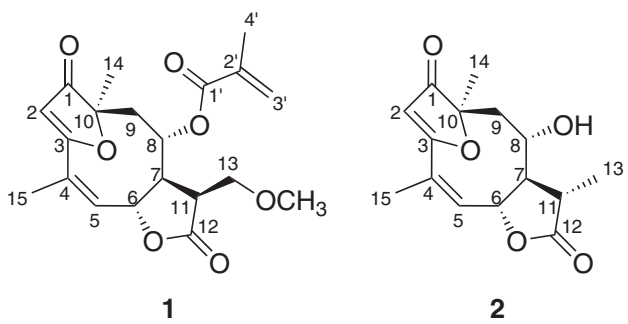

Figure 1. The new sesquiterpene lactones isolated from M. alpestris. 
IR spectra of compound $\mathbf{1}$ showed a intense absorption band at $1774 \mathrm{~cm}^{-1}$ due to the $\mathrm{C}=\mathrm{O}$ stretching of $\gamma$-lactones. ${ }^{7}$ ESI-MS analysis revealed the adduct ion at $\mathrm{m} / \mathrm{z} 399.1414$ $[\mathrm{M}+\mathrm{Na}]^{+}$compatible with a sesquiterpene lactone with molecular formula $\mathrm{C}_{20} \mathrm{H}_{21} \mathrm{O}_{7} .{ }^{1} \mathrm{H}$ NMR spectrum showed a singlet at $\delta 5.73$ which is characteristic for sesquiterpene lactones of the furanoheliangolide type, ${ }^{12}$ that usually occurs in the subtribe Lychnophorinae. ${ }^{14}$ Absence of the pair of doublets relative to exomethylene hydrogens gives evidence for the saturation between $\mathrm{C}-11$ and $\mathrm{C}-13$ which is not usual for furanoheliangolides of goyazensolide type. The signal at $\delta 2.55$ was attributed to $\mathrm{H}-11$ by ${ }^{1} \mathrm{H}-{ }^{1} \mathrm{H}$ COSY spectral analysis and related to the diastereotopic hydrogens on $\mathrm{C}-13$ ( $\delta 3.56$ and $\delta 3.73$ ). Based on the chemical shifts of these hydrogens it was inferred that a methoxyl group $(\delta 3.39,3 \mathrm{H}, \mathrm{s})$ must be bonded to this carbon. The $\alpha$-orientation of the acyloxy substituent at C-8 was established based on chemical shift of $\mathrm{H}-8(\delta 4.89)$ which contrast to $\delta 5.30$ when it is $\beta$-oriented. ${ }^{15}$ The relative configuration of the molecule was established by nOe difference spectroscopy. Irradiation of H-6 and H-8 affected $\mathrm{H}-2, \mathrm{H}-9 \beta$ and the methoxyl signals and both hydrogens must be "cis" (Figure 2). Therefore, the C-11 substituent was proposed to be $\beta$-oriented. ${ }^{13} \mathrm{C}$ NMR and DEPT $135^{\circ}$ showed signals of four methyl, three methylene, six methine and seven quaternary carbon atoms which were attributed by HMQC and HMBC spectra analysis.

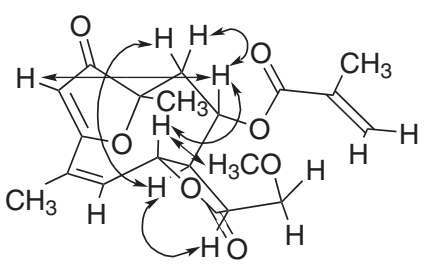

1

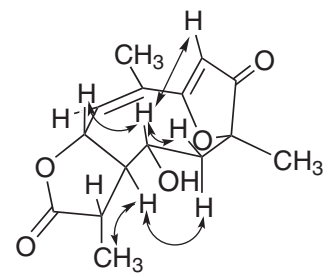

2
Figure 2. The nOe interactions observed by irradiation of H-6, H-7 and $\mathrm{H}-8$ signals.

The IR spectrum of compound $\mathbf{2}$ is similar to that of $\mathbf{1}$. However, a band at $3200 \mathrm{~cm}^{-1}$ gives evidence for a free hydroxyl group in the molecule. ESI-MS analysis showed the adduct ion at $m / z 301.1046[\mathrm{M}+\mathrm{Na}]^{+}$which characterize a sesquiterpene lactone with molecular formula $\mathrm{C}_{15} \mathrm{H}_{18} \mathrm{O}_{5}$. Analysis of ${ }^{1} \mathrm{H}$ NMR spectrum revealed that compound $\mathbf{2}$ is analogous to $\mathbf{1}$ with respect to saturation between $\mathrm{C}-11$ and $\mathrm{C}-13$. Absence of the $\mathrm{C}-8$ ester substituent signals and the upfield shift of $\mathrm{H}-8(\delta 3.76, \mathrm{dt}, J 2.0$ and $10.8 \mathrm{~Hz})$ when compared with 1 indicated a free C-8 hydroxyl group. Analysis of the coupling constants $\left(J_{7,8} 2.0 \mathrm{~Hz}, J_{8,9 \alpha} 10.8\right.$ $\mathrm{Hz}, J_{8,9 \beta} 2.0 \mathrm{~Hz}$ ) allowed to propose the $\alpha$-orientation for the hydroxyl, which is usually observed with sesquiterpene lactones isolated in the Vernonieae tribe. ${ }^{1} \mathrm{H}-{ }^{1} \mathrm{H}$ COSY was used to attribute the signals at $\delta 3.14$ (dq, $J 7.0$ and 10.0 $\mathrm{Hz}$ ) and $\delta 1.31(\mathrm{~d}, J 7.0 \mathrm{~Hz})$ to $\mathrm{H}-11$ and $\mathrm{H}-13$, respectively. ${ }^{13} \mathrm{C}$ NMR and DEPT $135^{\circ}$ data showed signals for three methyl, one methylene, six methine and five quaternary carbons. The assignments were based on HMQC and HMBC spectra. The $\alpha$-orientation of the methyl group at $\mathrm{C}-11$ was established based on its nOe interactions with $\mathrm{H}-7$ and $\mathrm{H}-9 \alpha$. Consequently, $\mathrm{H}-11$ must be on the opposite side with respect to these hydrogens. This orientation allowed a proximity between $\mathrm{H}-11$ and the lone pair of the $\alpha$-hydroxyl that can be visualized by inspection of a molecular model. This proximity causes a paramagnetic shift of $\mathrm{H}-11$ and a diamagnetic shift of C-11 as compared to $\mathbf{1}$ in accordance with observations by Tori et al. ${ }^{16}$ to the relative configuration proposed for both $\mathbf{1}$ and $\mathbf{2}$.

The results obtained from this study revealed that the chemistry of this species is in accordance to the Lychnophorinae subtribe. Considering that sesquiterpene lactones of hirsutinolide and glaucolide type are characteristic for Chresta and Vernonia, ${ }^{1}$ respectively, our data reinforces its actual taxonomic classification. Finally, the occurrence of furanoheliangolides in Minasia alpestris suggests that this herbaceous species can also be used as a potential source of these compounds, rather than other arboreous species of the subtribe under risk of extinction.

\section{Acknowledgements}

The authors wish to thank Prof. Walter Vichnewski for plant collection, Prof. João Semir for plant identification and Dr. Paul J. Gates for the high-resolution mass spectra and the English revision. This work was supported by CNPq, CAPES and FAPESP.

\section{References}

1. Robinson, H.; Smithson. Contrib. Bot. 1999, 89, 1.

2. Robinson, H.; Proc. Biol. Soc. Wash. 1992, 105, 640.

3. Rungeler, P.; Castro, V.; Mora, G.; Goren, N.; Vichnewski, W.; Pahl, H. L.; Merfort, I; Schmidt, T. J.; Bioorg. Med. Chem. 1999, 7, 2343.

4. Robinson, H.; Phytologia 1995, 78, 384

5. Robinson, H.; Phytologia 1997, 80, 350.

6. Marston, A; Hostettmann, K.; Nat. Prod. Rep. 1991, 8, 391.

7. Vichnewski, W.; Lopes, J. N. C.; Santos Filho, D. L.; Herz, W.; Phytochemistry 1976, 15, 1775.

8. Vichnewski, W.; Sarti, S. J.; Gilbert, B.; Herz, W.; Phytochemistry 1976, 15, 191.

9. Bohlmann, F.; Singh, P.; Zdero, C.; Ruhe, A.; King, R. M.; Robinson, H.; Phytochemistry 1982, 21, 1669. 
10. Bohlmann, F.; Zdero, C.; King, R. M.; Robinson, H.; Phytochemistry 1980, 19, 2663.

11. Borella, J. C.; Lopes, J. L. C.; Vichnewski, W.; Cunha, W. R.; Herz, W.; Biochem. System. Ecol. 1998, 26, 671.

12. Le Quesne, P. W.; Menacherry, M. D.; Pastore, M. P.; Kelley, C. J.; Brennan, T. F.; Onan, K. D.; Raffauf, R. F.; J. Org. Chem. 1982, 47, 1519.

13. de Vivar, A. R.; Guerrero, C.; Diaz, E.; Ortega, A.; Tetrahedron 1970, 26, 1657.

14. Herz, W. In Proceedings of the International Compositae Conference, Kew, 1994; Hind, D. J. N.; Beentje, H. J., eds.; Royal Botanic Garden: Kew, 1996, vol. 1, pp. 229-251.
15. Vichnewski, W.; Takahashi, A. M.; Nasi, A. M. T.; Gonçalves, D. C. R. G.; Dias, D. A.; Lopes, J. N. C.; Goedken, V. L.; Gutiérrez, A. B.; Herz, W.; Phytochemistry 1989, 28, 1441.

16. Tori, K.; Komeno, T.; Sangare, M.; Septe, B.; Delpech, B.; Ahond, A.; Lukacs, G.; Tetrahedron Lett. 1974, 13, 1157.

Received: April 7, 2003 Published on the web: March 15, 2005

FAPESP helped in meeting the publication costs of this article. 